\title{
Avihu Shoshana
}

University of Haifa, Israel

https://doi.org/10.18778/1733-8077.12.1.03

\section{Ethnographies of Maintenance of a New Self}

Abstract This article suggests expanding the discussion regarding the association between educationa boarding schools, social class, and one's sense of self, by examining the issue of how subjects who experienced reconstruction of the self continue to maintain this reconstruction as the years go by This issue is hereby discussed by way of the case study of the Boarding School for Gifted Disadvantaged in Israel. The subjects of study are defined as "ethnic" (Oriental) and, through the boarding school experience, State authorities carried out their intentional assimilation into mainstream culture. Study findings show that, over the years, boarding school graduates steadfastly participate in the school's annual Remembrance Day ceremony, in memory of the Fallen Soldiers of Israel (and specifically, the boarding school). Remembrance Day ethnographies and social gatherings held at the homes of boarding school graduates a few days before Remembrance Day show how participation in the Remembrance Day ceremony charges the graduates' sense of self-instilling in them the same structure that characterized their lives when they were students in the boarding school. Moreover, the structure of Remembrance Day itself (signifying the presence of absence) provides a (symbolic and narrative) charge, maintaining the boarding school graduates' sense of self and their national identifications.

Keywords Self; Self-Maintenance; Nationalism; Ethnicity; Re-Education; Boarding Schools

\begin{abstract}
Avihu Shoshana is a senior lecturer at the Facuty of Education, University of Haifa, Israel. Avihu's area of research include social psychology; discourse and subjectivity; ethnicity, race, and social class; culture, education, and self-concept; anthropology of education
\end{abstract}

email address: avihush@gmail.com schools"), on the other hand, are populated by members of the low socio-economic classes, also called "poor" or "disadvantaged" populations (Shoshana 2012a). These boarding schools operate mostly as assimilation institutions, whose objective is to bring about the re-education of its individuals (Wallace 1995). Many studies proffer rich ethnographies that describe how educational boarding schools use social and personal processes and practices involved in the social construction of the concept of self (see, e.g., Gaztambide-Fernández 2009b). One of the important research issues, which is not discussed sufficiently in the literature, and which may help to expand our comprehension about the connection between boarding schools and the self concept, deals with how individuals who experienced reconstruction of the self in their past (by way of a boarding school education or participation in a unique educational program; see: Zweigenhaft and Domhoff [1982] in this context) continue to maintain this same self-image, years after the (re)construction or the discursive institutional crafting of the self has occurred.

This article attempts to examine the ways in which individuals who have experienced an intentional intervention in their self during adolescence, via education in a state boarding school (the Boarding School for Gifted Disadvantaged in Israel), act with regard to this intervention. The Boarding School for Gifted Disadvantaged, operating since 1961 to this day, is an educational institution run by Israeli State authorities for students defined as "ethnic" (Oriental, or Mizrahim in Hebrew), living in peripheral areas ("development towns"). The school's objective is to help this population assimilate into Israeli culture (Shoshana 2012a)
The study findings show, for example, that over the years boarding school graduates willingly participate in the annual Remembrance Day ceremony, in memory of the Fallen Soldiers of Israel. This ceremony takes place at the boarding school once a year, as it does in every other educational institution in Israel (Goodman and Mizrachi 2008). Moreover, many graduates meet, year after year, a few days before Remembrance Day for a social gathering in one of the graduates' home. The study findings also show how Remembrance Day in itself becomes a happy social gathering, somehow taking on a structure similar to that of a wedding or celebration. A content and form analysis of Remembrance Day as a public event (Handelman 1998) reveals a unique integration of "Life" and "Death," as well as elements such as national mourning, sacrifice, and personal recollections of the student boarding school experience. These characteristics play a significant role in the self-maintenance of individuals who have experienced intentional reconstruction of the self. As will be discussed further, participation in Remembrance Day recharges the graduate's self with the same structure of detachment from one identity, and the attainment of another identity (rebirth), as acquired in the boarding school. Sahlins (1995) indicated a similar charge structure in his book on the King of Hawaii and Captain Cook. Every year, the king of the tribe comes to the ocean. From the bottom of the ocean, God appears and bestows the king with the authority to rule as his representative on Earth. Just as the King of Hawaii is charged by God or by Captain Cook, the graduates are similarly charged by their "creators," upon returning to the "house of creation" (the boarding school), and through the form of the boarding school's headmaster, who conducts the ceremony. 
It is worth noting that the structure of the Remembrance Day ceremony itself provides a (symbolic and narrative) charge. The configuration of the ceremony in Israel (and its association with Independence Day) provides a narrative meaning ("from Ruin to Redemption"), which maintains nationalism and a sense of one's personal self (Handelman 1998). Moreover, the Remembrance Day ceremony also signifies the presence of absence (Handelman 2004), and a sacrifice of the private self for the good of the nation as a whole. The presence of absence and the sacrifice are both central themes in the self-concept of the Oriental graduates whofollowing the conversion of their ethnic identity, which occurred when they were students-experience a dialectic between their "first nature" (biological or attributed Orientality) and what a number of graduates refer to as their "second nature" (the "Western" or "modern" self and cultural capital acquired at the boarding school).

Before describing the findings of the study in detail, I wish to discuss the relationships between boarding schools, social class, and the concept of self.

\section{Boarding Schools, Social Class, and Self}

Current ethnographies about elite boarding schools describe the processes of producing class and privilege (Gaztambide-Fernández 2009a; Khan 2011). Even if today's boarding schools offer accounts in the spirit of meritocratic idealism (Karabel 2005), they still operate as institutions that pass on cultural capital to the members of the elite class (or what Khan [2011] calls "democratic inequality").
In his study of an elite boarding school, Khan (2011:14) describes how the students learn to place their privilege experience within a framework (among other ways, by experiencing their self as exceptional and by achieving the understanding that hierarchies are natural), and how they develop privilege-“a sense of self and a mode of interaction that provides them with advantage." One of the insightful practices of privilege that Khan (2011) describes is affiliated with ease-feeling comfortable in just about any social situation. Privilege means being at ease. According to Khan (2011), the result of these processes is finding one's place. This expression echoes Bourdieu's (1977) description of learning the "rules of the game," as a critical resource for reproducing privilege (and social inequality) (for the construction of privilege in affluent schooling also see: Howard 2008). The constitution of an elite class identity is also described by Gaztambide-Fernández (2009a:6) by way of "the five E's of elite schooling: exclusion, engagement, excellent, entitlement, and envisioning."

While the explicit purpose of the admissions process is to choose who will be allowed inside, the implicit purpose is to exclude and to provide a rationale for such exclusions. Once admitted and enrolled, students engage a plethora of learning opportunities in a wide range of academic, athletic, and artistic disciplines that rival those available at many small liberal arts colleges. As students develop their talents and demonstrate their excellence, they confirm their entitlement to the privilege of a Weston education. At the end of their Weston careers, students envision themselves in other equally elite spaces, pursuing challenging careers and assuming leadership roles. (Gaztambide-Fernández 2009a:6)
Boarding schools are connected with class, even by way of the processes linked with social mobility. Cookson and Persell (1991) describe, for instance, how African American students report a process of isolation from their families as a result of their boarding school education, and the absence of full integration into the White upper class. As a result, the students feel like "outsiders within" and experience "acting upper class" and the "burden of acting White" in both cases. Cookson and Persell (1991:20) claim: "Part of the burden may stem from the students' realization that they can only 'act' the part." Even Gaztambide-Fernández (2009a) describes the unique experience of students from ethnic and racial groups in prestigious boarding schools and identifies them. These students, for instance, feel the pressure to assimilate, ambivalent belonging ("being in but not of this elite boarding school world" [Gaztambide-Fernández 2009a:164]), and are not sure why they were accepted to the school. One of the results of this experience is what Gaztambide-Fernández (2009a) calls "unequal distinction."

It is worth nothing that what is common to the main target population of the elite boarding schools-upper class students-both in the United States and in England (Weinberg 1967), is that the boarding school education does not seek to create social alienation between the family culture and the boarding school culture. Boarding school students are expected to acquire a character (or "cultural capital" in Bourdieu's terms) that suits the culture of their family. This issue is extremely important since it did not appear in boarding schools that were offered for subaltern populations in the United States (Wallace 1995) and in Israel (Shoshana 2012b).
The boarding schools that were established in the first years of the creation of the State of Israel (1948) were offered mainly to Jewish immigrants and descendents of immigrants from Islamic countries, called "Orientals" (and considered "ethnic" subjects). These boarding schools were created with the aim of re-education, in an attempt to phase-out "Eastern" culture and encourage the adopting of the "Western" cultural capital, which is described as more suitable to modern conditions. Like in other places in the world, the popular research in Israel discusses the everyday organizational work involved in the creation of a new self in boarding schools or in practices linked to the reconstruction of the self. This means that we do not know enough about how individuals who experienced reconstruction of the self (via boarding school education) maintain their selfhood years after this construction. This article seeks to fill this research gap. Before doing so, I would like to describe the research design and the institutional establishment of the new self in the Boarding School for Gifted Disadvantaged in Israel.

\section{Research Design and Methods}

The study of the Boarding School for Gifted Disadvantaged in Israel is based on three kinds of data used to understand the social origins of the boarding school, its purposes, educational practices, and the work involved in the construction of the new self. Content analysis (Strauss and Corbin 1998) was performed on governmental protocols and organizational reports relating to the establishment of the boarding school. The documents analyzed were protocols of the Education and Culture Committee discussing the educational boarding school (late 
1950s and early 1960s); documents kept in state archives concerning the educational boarding school; organizational steering reports written by the enterprise initiators and those who were responsible for its operation in the Ministry of Education; and brochures produced by the boarding school headmasters, since its establishment to this day (for a description of the complex content analysis, see: Shoshana 2012b).

In order to understand the effects of a boarding school education, and of the processes involved in reconstruction of the self, I conducted interviews with 60 boarding school graduates from different classes -15 graduates from each decade (1960-2000). Throughout the years, approximately the same number of students studied in the boarding school in each class. Altogether, 40 men and 20 women were interviewed. These numbers corresponded to the percentage of boys and girls who studied in the boarding school over the years. I conducted the interviews in coffee shops, in the university offices, or in the homes of the interviewees. Each interview took between two and four hours. Most graduates have an academic degree ( $60 \%$ have a BA, $15 \%$ have an MA). Most of them live in big cities (approximately 90\%) rather than in the development towns in which they grew up as children and where their families still live. Approximately $60 \%$ of graduates reported an above-average income and a professional occupation requiring an academic degree(s) (for a specific description of the sampling methods, interview structure, and key findings, see: Shoshana 2012b).

Following the reports of many graduates (80\%) about their consistent participation in the boarding school's annual Remembrance Day ceremony, I decided to conduct observations on these occasions. Altogether, observations were conducted on three Remembrance Days (2002-2004). ${ }^{2}$ The Remembrance Day ceremonies began in the afternoon. Each time, I arrived approximately three hours before the ceremony began in order to observe the preparations for the ceremony and the reception of graduates by boarding school representatives. In addition, I learned from the interviews that a few groups of graduates (from different classes) meet about a week before Remembrance Day for a social gathering held in the evening at the home of one of the graduates. Altogether, I participated in four such social gatherings between 2003 and 2006.

This paper is based on the findings from Remembrance Day ceremony observations conducted in

${ }^{1}$ It can be hypothesized that participation in the Memorial Day ceremony is not connected to the self-maintenance of boarding school graduates. Together with this, I suggest that we canno ignore the fact that $80 \%$ of the graduates reported on their regular (yearly) participation in the boarding school Memorial
Day ceremony. $10 \%$ of the remaining $20 \%$ reported that they Day ceremony. $10 \%$ of the remaining $20 \%$ reported that they attend less frequently. $10 \%$ (6 out of 60 interview

${ }^{2}$ The findings of my study depict dramatic differences in the accounts of those who participate regularly in Memorial Days at the boarding school and those who do not participate. The latter do not perceive the boarding school as being directly responsible for their life achievements, nor do they experience two types of self (what I call "first nature" and "second nature" selff. I am not saying this is the sole reason affiliated with the
self-concept. The identity work that was executed at the boarding school (as a total institution) was dramatic and may explain the self-concepts that I discuss (also see: Shoshana 2012b). At the same time, it is important to point out that the choice of many of the graduates to participate in the annual Memorial Day ceremony is certainly very intriguing. Illustrating the structure and content of the Memorial Day ceremony, as I describe throughout the study, matches the reconstruction work of the self that was implemented at the boarding school. The
integration of these two characteristics (the organizational work at the boarding school and the regular participation in the annual Memorial Day ceremony) has a significant influence on the maintenance of the self-concept among the boarding school graduates. the boarding school, and from the social gatherings in the homes of graduates. Additionally, in order to build a complex understanding of the reconstruction of the self, I would like to begin with a description of the background leading to the boarding school's establishment, its objectives, and operational modes.

\section{State and Self in Everyday Life: The Case Study of the Boarding School for Gifted Disadvantaged in Israel}

The founding of the Boarding School for Gifted Disadvantaged in Israel in 1961 was closely linked to the attempt of State leaders to establish a state national identity in Israel's early years. Upon the establishment of the State of Israel in 1948, State leaders were occupied with what was then referred to as the "demographic threat," in other words-the fear of a Jewish minority and an Arab majority in Israel. One key solution found for this issue in the first years after the establishment of the State was to bring massive numbers of Jews from Arab countries to the new State of Israel. However, the migration of these Jews from Arab countries brought with it a new problem, called the "cultural crisis" (Shohat 1999). The dominant political elite in Israel (mostly east-European Jews) was troubled by the culture of these new-immigrant Arab Jews. This culture, described as "primitive," "traditional," and "anti-intellectual," was perceived as inappropriate and even dangerous to modern culture (defined as typical of European and north-American Jews, referred to in Hebrew as Ashkenazi) and to the model of the "new Jew" the State leaders wished to establish and encourage in the spirit of the West (Almog 2000). In order to solve this cultural crisis, the state educational system in Israel was harnessed. Under these circumstances, the Boarding School for Gifted Disadvantaged started operating, and still operates to this day, offering an educational opportunity mainly to Mizrahi students from the years of early adolescence up through high school graduation. The main objective of the boarding school was phrased as follows:

An enterprise based on removing teenagers from their communities at the onset of adolescence, providing them with intellectual missions of high academic level requirements in high school, and placing them in competition with children of European origin from middle class families. (Smilansky and Nevo 1970:9)

This formal aim earned a number of specific definitions in the form of formal and non-formal education programs emphasizing three interventions: cognitive, emotional, and normative. Cognitive intervention included the development of thinking skills such as rationality, critical thought, increased ambition, postponement of gratification, and future-oriented self. Emotional intervention described features such as independence, initiative, and high self-esteem. Normative intervention mainly included exposure to what was described as quality cultural performances or cultural enrichment, such as going to the theatre and participating in book clubs. The means to these ends were varied: living in an inclusive institution (Goffman 1961) (physical distance from the family home; weekend visits home about once a month); a strict daily schedule including studying at school in the mornings alongside "middle-class students of European origin" (Smilansky and Nevo 1979:9); and numerous non-formal educational activities (such as visits to the 
theatre). Students of European origin were used as role models to encourage the Oriental students to acquire the new cultural capital. These personal and cultural objectives were also described by the boarding school initiators as objectives able to fulfill social functions, such as communicating messages and limits to society members as a whole, and to the marginal groups within it: "Each of their group members can fulfill their aspirations for mobility and social status on a personal-achievement basis; it is unnecessary to demand status rights on an attributed-group basis" (Smilansky and Nevo 1970:11).

Interviews with the graduates show how they experienced their boarding school education as a positive event, responsible for their social-economic mobility. The boarding school education is described as a "rescue initiative" and as a gift of the State to its "ethnic" (Oriental) and "poor" citizens. The education in the boarding school is described as a life event that leads to the creation of a new self (Shoshana 2012a), including specific features (such as rationality, curiosity, ambition) that were not characteristic of the original, pre-boarding school self-the Oriental self, and the self still reflective of their family at the time. Actually, this self includes a specific reflexivity that embraces two types of self (the preand post-boarding school self-the Oriental self and the Western self) and two types of nature (first and second nature) (Shoshana 2012b). "Second nature" is an explicit term raised by a number of graduates. It refers to the ("Western") self acquired following the education received in the boarding school, which included a specific cultural capital better suited to "modern" life conditions. This cultural capital (or second nature) is constantly experienced with reference to the first nature, described as "Oriental," "primitive," or "uncultured." Most of the boarding school graduates also described their need to maintain a distance from their first nature, identified with low socio-economic status and with a sense of ethnic awareness (Shoshana 2012b).

\section{Ethnographies of Remembrance Days and Maintenance of the New Self}

One of the recommendations that many graduates gave me was to arrive at the boarding school on Remembrance Day. When I asked, "What makes this day special?," the answers were more or less the same: "It's the essence of the boarding school"; "Without it, you can't really understand this place." These answers encouraged me to contact the organizers of Remembrance Day at the educational boarding school. In 2002, about a month before the national Remembrance Day ceremony in memory of the Fallen Soldiers of Israel, I met with the boarding school headmaster, introduced myself, and asked to participate in the Remembrance Day ceremony. I received his approval, accompanied by a challenging remark, "I have no doubt that this will help you understand this special place; that's all I'm going to say." Subsequently, I participated in two additional Remembrance Days. During the first Remembrance Day in which I participated (in 2002), I closely observed the structure of the ritual and its logistics, as anthropologist, Don Handelman (1998), suggested. On the second Remembrance Day (in 2003), in addition to unplanned observations, I wanted to conduct a planned observation of an issue that had caught my eye during my first observation-the public exposure of what was defined as the boarding school graduates' "successes." On the third Remembrance Day (in 2004), after identifying the consistent participation of many graduates in the Remembrance Day ceremony, I tested, in a scheduled manner, the meaning of this consistent participation in a "public event" (Handelman 1998) among many of the graduates.

\section{Three Ethnographies of Remembrance Days}

The Form of Remembrance Day and the Content of a Celebration

The Remembrance Day ceremony is held in the boarding school's central courtyard, like any other Remembrance Day in memory of the Fallen Soldiers of Israel held across Israel on that same day. Upon arrival, at the entrance to the educational boarding school, about two hours before the ceremony began, I already found the boarding school headmaster standing and waiting to welcome the participants. At his side stood boarding school students, teachers, and instructors who had participated in the event's organization. The boarding school headmaster stood in the doorway of an iron gate, separating the boarding school premiseswhere the ceremony was to take place-from the area outside the boarding school. The headmaster shook hands with each graduate, after which he or she was free to enter the premises. Slowly, bunches of graduates began gathering in the area in front of the boarding school's entry gate, as I later found out, according to their graduating class. These groups of graduates were laughing, hugging, shak- ing hands, and mostly engaging in nostalgic conversations. This part of the event took about two hours, until the boarding school headmaster asked everyone present to enter the central courtyard in which the ceremony was to be conducted. The structure of the Remembrance Day ceremony was no different than those ceremonies conducted in other educational institutions: State symbols (flags, candelabrum), candles, texts, songs, and a reading of the names of Fallen Soldiers (Lomsky-Feder 2004). The ceremony is typically quiet, in contrast with the commotion typical to what goes on before the ceremony. The graduates sit down in groups, according to their graduating class; for the most part, they are silent, as per the instructions of the ceremony's organizers. It is also worth noting that the ceremony itself is relatively short (about thirty minutes), compared to the entire event. After the declaration, "the ceremony has ended," participants return to the joyful commotion that characterized the event before the Remembrance Day ceremony, conducted in accordance with the Ministry of Education's guidelines. The structure of the post-ceremony celebration is similar in shape and content to the pre-ceremony interaction: cheers are heard, conversations take place among individuals gathering according to their graduating class, and graduates from different classes shake hands and become reacquainted with one another.

However, this third part of the public event has one unique feature. The groups of graduates sit down together and reminisce in a more organized manner than they did previously. Earlier, an individual recollected a certain experience and some of the others listened, but now this is done collectively, 
and there is no jumping from one nostalgic memory to the other; the group lingers on the specific details of each memory. Moreover, what distinguishes this part of the celebration from the former interaction is that in the end, the graduates exchange telephone numbers and addresses, set a tentative date for a gathering, choose a number of graduates to be in charge of organizing it, and say goodbye. I believe we can best learn "what goes on Remembrance Day" from the words of Orna, a graduate of the class of 1983:

\section{AS: So what's so special about this place?}

Orna: Where else have you seen this kind of Remembrance Day?

AS: What kind?

Orna: The happy kind.

AS: But, it's Remembrance Day.

Orna: Yes, but it's also a happy day, like a special event, even like a wedding.

\section{AS: Why is it like a wedding?}

Orna: Each of us feels like a bride and groom, this place is our canopy ... the boarding school is our parents ... today, just like in the old days.

In order to promote our understanding of public events and the function they fulfill, Handelman (1998) suggests we identify their structure and internal logic. A day that is formally declared as a commemorative day, and which actually becomes a festive day ("like a wedding day"), raises an important question: How is it that one organizational form is "transformed" into a different organizational form? What is the internal logic of this structure and how is it related to the individuals' notion of self?
Remembrance Day at the boarding school, a death-related event, is filled with content reflecting that of a day of celebration, a life-event, or a celebration of life. It is worth noting that Remembrance Day does not only become a class reunion, as do many Remembrance Days in Israel (Lomsky-Feder 2004), but rather it becomes a festive event, a happy meeting, a celebratory day in Israeli culture. The reception in the entrance to the courtyard very much resembles the reception conducted by the parents in an Israeli family event (such as a wedding, bar mitzvah, or brit milah). The parents shake hands with the guests, and welcome them to the event. Similarly, the group gatherings according to graduating class may remind an observer of the seating arrangements at a celebration, according to category, such as "workplace," "friends," "family," et cetera. Even the structure of what was called an "acquaintance trip" resembles the rotation of acquaintance and thanks performed by the parents of the bride and groom, and the bride and groom themselves, as they visit and mingle among the guests' tables. Erez, a graduate of the class of 1995, expressed this in an interesting way:

I've been to other Remembrance Days, and this one doesn't come anywhere near what you are familiar with. Don't expect grief, it's mostly fun [silence], it's more of a party. Not that there is sorrow for the dead and stuff like that, like we're used to, um, remembrance and all that [silence], it's probably strange for you, but that's how it is in the boarding school, there's a lot of strange stuff, out of the ordinary.

These words reminded me of the explicit wedding metaphor Orna had suggested, as described above.
One possible answer to the query, "How is it that a day of death becomes a celebration of life?," relates to the centrality of the "death" (symbolic death) and "life" (rebirth) features in the organizational work of the boarding school. My claim is that the Remembrance Day ceremony functions as a "charging" ritual. The structure of the ceremony charges (or recharges) the graduates' notion of self, using the same structure used years earlier when they were students at the boarding school-the detachment of one identity and the taking on of another identity (rebirth). Thus, I define charging rituals as those repetitive rituals that reinforce, and thus maintain, a personal, collective, or national identity. In other words, a charging ritual is a type of maintenance ritual that replicates a meaningful life experience through the repeated structure of the ritual. The words of Erez, a graduate of the class of 1995, draw attention to this charging aspect:

There's no way I would miss the Remembrance Day ceremony, no matter where I am. In the army, they even wanted to put me on trial for splitting and coming here. But, nothing could keep me away, it's all just a waste of time, I need to breathe in the air of this boarding school once in a while, it's like an infusion, like a drug.

The symbolic death (the boarding school graduates' parting from their Oriental self and from their "first nature"), or actual death (Israeli Fallen Soldiers), and the experience of life (rebirth) that coexist within the structure of the charging ritual replicate the organizational identity of the boarding school, the personal identity of its students, and the national identity of its creators (the State of Israel). The common features of the structure of Remembrance Day and the graduates' encounter with the boarding school is, as I shall describe in the discussion section, a case of the sacrifice of the subject for the good of the organization (the State or the boarding school) and the presence of absence (Handelman 1998).

\section{The Pride of Giving a Gift (in Return)}

On the second Remembrance Day I observed, I accompanied the boarding school headmaster on his "acquaintance trip." In a conversation he had with one of the graduates, who was then in basic training in the Paratroop Corps, the boarding school headmaster told the young soldier:

Take a good look, Ofir, this is everything you need to see, everything you will be in a few years: second lieutenant, lieutenant, lieutenant colonel, I'll introduce you to him, and afterwards, it's not over. Ayelet is a law student, Hertzel has a successful private office. So go on, mingle, shake hands, it'll help you. I'm going to talk to Ami, he's the Israeli representative somewhere in the U.S.

One of the things that caught my attention was the many conversations about the achievements of the graduates participating in the ceremony, and the symbols of success associated with these achievements. The Remembrance Days observations allowed me to identify not only graduates of various ages and graduation classes participating in the event, but also graduates in the midst of different life stages. This identification was made possible mainly through symbols associated with life stages 
or through verbal information communicated by the boarding school representatives and the senior graduates. The life stages were in accordance with the milestones of the "normative" socialization of the individual in Jewish-Israeli society:

Army $\rightarrow$ University $\rightarrow$ Post-University (professional occupation) $\rightarrow$ Marriage $\rightarrow$ Parenthood $\rightarrow$ Professional Achievements

Upon graduating from the boarding school, the graduates are recruited to the army, like other eighteen-year-olds in Israel. Here, the achievement-identity is already visible: recruits in selected army units (IDF uniform); soldiers who completed basic training in a selected unit (the red army shoes and red beret of the Paratroopers); officer training cadets (officer pins); young officers (second lieutenant, lieutenant), and senior officers who climbed up the ladder of military rank (lieutenant colonel). The next prestigious post-army step is attending the university. Here, too, one can identify the "successful self." The boarding school representatives only point to those students who study in the more prestigious faculties: law, accounting, medicine. The next obvious stages in the "successful self" life course involve finding an occupation, settling down, and establishing a family. In the acquaintance trip held on this day, the graduates are introduced to former students who have achieved prestigious profession: lawyers, doctors, academicians, et cetera.

I perceive the participation of various graduates in Remembrance Day and the indication of achievements as a symbolic act of giving a gift in returnthe graduates are giving a gift in return to the ed- ucational boarding school (a representative of the State of Israel). Many graduates report this explicitly. Moreover, the "successful self" is organized around an axis of gifts, moving forward linearly (basic training in a combat unit, serving as an officer, university, a prestigious profession), and the progression along this axis is a testimony of the deep and repeated imprinting of the new self the graduates were offered and took on in the boarding school.

Observations of the gatherings in the boarding school courtyard and the interviews I conducted with the event participants show that the central issues discussed on Remembrance Day are not related to death, but rather to life and the continual rebirth of the former boarding school students. The boarding school graduates pay tribute to the educational institution that is responsible, in their eyes, for this rebirth.

In light of the above, my claim is that Remembrance Day becomes a day of celebration in which the boarding school graduates pay tribute to the entity (the State of Israel) that gave them the gift (their new self) via their ongoing attendance at the ceremony year after year, their open praise, and the display of their gift-giving in the public courtyard of their own personal "house of creation." The praise given to the entity that bestowed the gift of new life is even manifested in a type of emotional and verbal admiration-of that "gift," which is perceived as given by the State. This admiration is positively manifested in the form of graduates who display this gift on the very day, and the fruitfulness of the entire educational enterprise (army promotions, prestigious uni- versity faculties, prestigious professions, and even male and female graduates who decide to marry and have children together). The fixed admiration also maintains the relationships between the boarding school graduates and its operators via what Appadurai (1985) described as asymmetrical gratitude between social classes. Many graduates report a chronic gratitude or appreciation to the boarding school as a representative of the State. Appadurai (1985), who described an exchange of gifts between and within Tamil social classes, showed how praise to the gift-giver appeared under structural or permanent relations of subordination. A farm laborer could not praise the "thickness of the cloth" or the "sweetness of the rice" that he received from his patron, so as not to appear insubordinate. He must praise the patron (the gift giver) rather than the gift itself. Praising the gift itself is reserved for individuals from the higher class.

\section{A "Root Trips" to the Second Nature}

You come here and take in the smells, look around the rooms. You see a drawing on a tree, a souvenir you once hid ... It gives you strength, reminds you where you came from and where you are going. It's more than that, though, you know? It's like, like, it's like, um, it's like a sacred place ... every time I come here, even the air here is different, my breath. (Rachel, graduate of the class of 1977)

Rachel's description is not uncommon. Many other graduates, mostly those who arrive each year at the boarding school on Remembrance Day, describe their participation in the ritual as something that distinguishes between the world of sanctity and that of profanity, in Durkheim's (1915) sense. Tzipi, a graduate of the class of 1987, whom I interviewed after my first Remembrance Day observation, described her experience in religious terms. Her answer to my question, “What's special about this day?," aroused my curiosity: "It starts long before the actual day because we plan it in advance, we carpool. You see, we make a day out of it. We go back to being kids, as if twenty years gone by." I met Tzipi again on the second Remembrance Day in which I participated, and in our conversation, she once more described the "early preparations" she mentioned (the carpooling) and she offered, seriously or not, that I join them next year.

About two weeks before the Remembrance Day celebration at the boarding school in Jerusalem, Tzipi called me and said: "A few friends from the boarding school are getting together next Thursday at my house, it might interest you, you can kill a few birds with one stone." I immediately replied that I would love to join them and asked what the purpose of the gathering was. Tzipi explained, “Oh, we meet every year a few days before Remembrance Day." I asked: “Who participates?" Tzipi replied: "It's been the same group of friends for the past 10 years or more, close friends from the boarding school." I asked again about the purpose of the gathering, and Tzipi said, "There's no particular purpose, it's become a tradition, just a pleasant evening. Of course, we talk a lot about the boarding school, so I thought it would be appropriate if you came." The social gathering took place on a Thursday evening at Tzipi's house. The gathering included eight former students, four men and four women. When I arrived at Tzipi's house at 8 p.m., I found Eli helping Tzipi 
arrange the yard before the other friends arrived. Tzipi introduced me to Eli, and he added: "So you're studying the boarding school. Wow, you'll get plenty of good material tonight."

This kind of gathering has traditionally taken place every year since 1994, a few weeks before Remembrance Day, with a regular core of eight graduates, who also faithfully attend the Remembrance Day ceremony in Jerusalem. It is worth noting that the graduates' spouses do not come along. I asked Tzipi and Eli why, and Tzipi replied: “It doesn't work, we tried it one year and it was bad. You remember, Eli, it wasn't the same, so we decided to stop it." As for the evening's plan, Eli said, "A lot of food and laughs, nothing heavy." Tzipi replied: "Mostly food, like in the boarding school, you'll see, we have a barbecue, everyone brings something ... we remind each other of experiences from the boarding school. Like I told you before, you'll see for yourself, we go back to being kids."

Gradually, the other six graduates arrived at Tzipi's front door. Each of the graduates was welcomed with hugs and kisses, after putting the dish they brought for the evening on the table. It is worth noting that every participant, so I was told, brings the same dish every year. When I asked Ilana why, she answered: “Each of us brings something from our family home. I'm Kurdish, so what do I bring? Kube." When I asked Shuli what she had brought, she said: "My specialty is stuffed vegetables." Amos commented: "Moroccan food, what else?" Right after that Eli came and urged Amos to "start the fire." Amos complained and replied: "Every year I get stuck with it." "Get stuck with what?, I asked. "The grill, the barbecuing." Ila- na and Shuli laughed, and Shuli commented: "He never stops complaining, even when we were in the boarding school he was a whiner. Even then he used to barbecue on Independence Day, on Lag Ba'Omer. Nothing changes." Ilana added: "But, we forgive him, nothing beats his kebab."

At this point Kobi told us to take a seat around the table in the yard and start eating. During dinner, I expressed my special interest in the timing of the gathering (before Remembrance Day). Dudi replied, "There's no special reason, it just became a tradition." Tzipi said: "Yes, but I think that what we have here doesn't exist anywhere else ... we've had experiences together, I'm being serious now, tough experiences." When I asked Amalia whether she agreed, she replied, “Totally, but it's a bit absurd. [Turning to Tzipi] How do you explain the fact that, all in all, we came out okay?” Tzipi replied: “That's beside the point, but there was pain, you're just forgetting." Tzipi turned to Eli and encouraged him to tell me how they both picked up two other friends, who lived in towns in the south of Israel (including entering Kiryat Gat, a development town), on the way to Jerusalem.

"The trip brings us right back to the boarding school, even the stop in Kiryat Gat," Eli explained. “Why?," I asked. "Because all development towns look the same," Eli replied and smiled at Tzipi. When I asked them both to explain what he had just said, Eli replied: "I thank God, or better yet, the boarding school, that I didn't stay there. I could have easily stayed there."

Now Shuli joined in on the conversation and asked: “What about Kiryat Gat? Did they treat you nicely?
... Because if they didn't, I'm sending them back to Kiryat Gat." Eli and Tzipi laughed and explained to Shuli that we were talking about "the places where we came from, like Kiryat Gat." I said that I had asked them to explain their attitude towards Kiryat Gat, as a model of a development town in their eyes. Shuli said, “There's not much to tell. It's an ordinary development town. It just reminds us of the boarding school because the boarding school saved us [from living in a development town]." Tzipi replied: "Here we go again with the saving. It's not exactly that, I don't agree." Shuli claimed that Tzipi "always liked to see the glass half full ... she'd always been a romantic, she tries to see the best in everyone. It's nice, but it's also optimistic." Eli told her: "You don't want to change," and turning to Tzipi, he commented, "Why don't you tell him about our annual outing ... every year we eat someplace else." Tzipi laughed and explained that it is an "inside joke." I asked them to fill me in on the joke, and Tzipi replied: "Where do we eat? Every year we eat at Sima's [an Oriental restaurant in Jerusalem]." Shuli added, "Eli was always interested in where we were going to eat, even at the boarding school, it was his job." Eli replied: "I hear you complaining, maybe this year we'll go to a different place." Tzipi swiftly replied: “Don't start, who are you kidding, anyway, every year we talk about going to a different restaurant, it's not going to happen. Sima is us, come off it." I was interested to know why they chose Sima's restaurant. Eli replied: “Where can we go, to 'Eladve'Zehu' [literally: 'Elad and that's that'-the name of an 'Ashkenazi' restaurant in Jerusalem], it's not appropriate, we prefer 'Simave'Zehu.'” They burst into laughter, and laughed for a long time. In the end, I asked why Sima is more appropriate. Eli replied: “Take a good look at us, don't you think Sima is more appropriate?" I did not let it go and pressed them for an answer. Eli said, "I don't know, it's just more appropriate.” Tzipi interrupted him and said: "He meant that boarders won't set foot in 'Eladve'Zehu,' it's not appropriate. He's right." I told her: "But, you're no longer boarders." Tzipi immediately responded: "Honey, being a boarder is in your genes, write that down ... boarders sit at Sima's, period." Eli looked at me and said: "I told you, she's fearless."

I wish now to portray the boarding school as a site of "pilgrimage" for maintaining personal and community identities (see: Howe [2001] for a description of the pilgrimage to San Francisco by many homosexuals, as a practice for maintaining personal and collective identities). The graduates leave their new home, where their ("Western") boarding school self exists (prestigious towns), pass through the regions of their past ("Oriental") identity (preliminary gatherings, entering development towns and Sima's restaurant), and arrive at their place of (re)birth-the center of their second nature. The term "second nature" was explicitly used by a number of graduates who referred to the self acquired following the boarding school education and fitting the institutional self, including values of meritocracy, entrepreneurship, self-reliance, or what was also referred to as the "Western self." My claim is that the pilgrimage replicates symbolic death, rebirth, and especially a therapeutic sense of spiritual and cultural redemption, in the same way it occurred during their childhood, and as occurs on all types of pilgrimages (Turner and Turner 1978). 
In order to support my claims concerning the graduates' pilgrimage, I shall henceforth describe the occurrences, starting with the moment when the graduates arrive at the "pilgrimage site" (the boarding school) in Jerusalem.

Upon arrival at the boarding school gate, the graduates first greet the boarding school headmaster, who shakes their hands and allows them to enter the boarding school premises. It seems that most graduates know the boarding school headmaster. Thus, the boarding school headmaster serves as a sort of barrier between the inside of the boarding school and the outside area, and he is the one who permits graduates to enter. This makes the passage through the gate a type of ritual, clearly distinguishing those who are outside from those who are inside. Upon entering the gates, the participant "passes through" as a graduate. The Remembrance Day ceremony begins with the words of the boarding school headmaster. His speech explicitly presents the self recharging function. The boarding school headmaster clearly emphasizes the purpose of the ceremony:

Hello everyone, I'm happy you came. This is a difficult day for the State of Israel, but like in Israel-grief and joy go together. We have convened today to pay our respects to the dead, those who sacrificed their lives for the country ... I look at you and I'm filled with pride ... This happens to me every year and I am still surprised anew, each time, you are the true pride ... every year coming from afar, this is our real success ... good education can rescue you from the bottom . we are the proof ... that you don't have to be stuck in the periphery ... This is a difficult day, but this is also a special day for us, the boarding school family
.. and the Israeli family ... I've been in the field of education for many years now ... I've worked in many organizations, but what goes on here is truly unique ... this is our success ... I'm sure you, too, feel how easy it is to go back to childhood ... you just need to go inside ... We will begin the ceremony, but remember it doesn't end here ... We all know we're not only here for Remembrance Day.

If, thus far, the symbolic death (as a disadvantaged individual or Oriental) and rebirth as a student (or graduate) of the boarding school (or as a new self) were unclear, now the boarding school headmaster has explicitly declared it. After the ceremony ends, the graduates gather according to their class once again. This time, the conversations are different. Now the graduates begin to exchange telephone numbers, set dates for upcoming gatherings, try to set a date for a class reunion, and mostly promise to "keep in touch." If, before the ceremony, the sense of communitas (Turner 1969) primarily included "recollection actions" (Urry 1990) about constitutive moments related to the second nature (or the new self), after the ceremony, it includes plans and action for the future maintenance of this sense of sharing a "common destiny." The structure of Remembrance Day and the sacrifice it entails encourage, as I shall describe below, the experience of transformation, necessary for the maintenance of the "second nature" or the reconstructed self.

\section{Discussion: (Re)Charging the Self}

The case study of the Boarding School for Gifted Disadvantaged in Israel raises a number of questions, important for understanding the mainte- nance of the reconstruction of the self: Why did the heads of the boarding school specifically choose Remembrance Day, which contains the presence of absence (Handelman 2004), as the annual meeting day of its graduates? Why do so many graduates insist on participating regularly (every year) in this ritual? Why does a one-time dramatic "pilgrimage," typical to a root trips back to one's "first nature" (Feldman 2008), not suffice in this case? What is it about the form and content of the public event (Handelman 1998) that fulfils the transformation of the self or the replication of the experience of reconstructing the self?

Many interviewees described how, over the years, various attempts were made to arrange a gathering of boarding school graduates on Independence Day or during the summer vacation, instead of on Remembrance Day, usually identified as a day of death. In other words, various graduates tried to separate the graduate gatherings ("a day of celebration") from Remembrance Day ("a day of death"). This point may be an answer to the question of why Remembrance Day was specifically chosen as a day of celebration. The replication of the graduates' life experiences takes on a special meaning on Remembrance Day. My claim is that the structure of Remembrance Day reflects a type of shortcut (has heuristic qualities) since Remembrance Day, according to the rationale proposed by Handelman (1998), is a day of sacrifice that includes elements of the social drama, necessary for the personal (graduates), institutional (boarding school), and national (State of Israel) narratives. The structure creates the narrative meaning necessary for maintaining the special self created in the boarding school.
This claim is based on the explanation that Handelman (2004) suggests for the structure of remembrance rituals in Israel (Holocaust Remembrance Day, Remembrance Day in memory of the Fallen Soldiers, Independence Day). According to Handelman (2004), this semiotic structure creates a narrative meaning and is not "coincidental," "natural," or "necessary." This structure offers a specific narrative for the citizens of Israel, which serves the $\mathrm{Zi}$ onist (national) cosmology in Israel-from ruin to redemption, from holocaust to revival, from chaos to cosmos (Handelman 1998:231). Holocaust Remembrance Day reflects the chaos of the past and is a warning against contemporary potential dangers; Remembrance Day in memory of the Fallen Soldiers reflects the battles that have been necessary to maintain the nation State; and finally, Independence Day celebrates victory, the present condition of the nation State. The result of this narrative structure is a reconstitution of Jewish national identity in Israel. Similarly, I argue that the structure of the ritual and its contents, linking the day of death and the day of celebration, "charges" the boarding school graduates and maintains their reconstruction of self, closely related to the national identity of the State of Israel. This charge is manifested not only symbolically (the link between death and rebirth) but also via replication of the logic upon which the boarding school's organizational work is based-the conversion of the Oriental self to a Western (or "Israeli") self, or replacing the first nature with a second nature. The Western self or the "second nature" are described, by both the boarding school authorities and the graduates, as necessary for the establishment and maintenance of the State of Israel and its survival under the conditions of modern life. 
This charging also means a replication (or current contemplation) of the unique reflexivity of boarding school graduates, following their participation in an assimilation-directed State organization. The research findings show how graduates contemplate "first nature" (Oriental self) and "second nature" (Western, Israeli, or modern self) or their proximity (via personal characteristics, achievements, or cultural tastes) to each kind of nature. This reflexivity means a contemplation of the "presence of absence." This absence relates to the characteristics (identified as "Oriental" or a notion of self) that existed prior to the boarding school experience. Participation in the Remembrance Day ceremony in the boarding school courtyard is a reminder of the act of conversion performed in the boarding school, which reflects, inter alia, the presence of this absence.

The practice of participating in Remembrance Day is supported by a series of additional practices that charge the new self and reinforce the reconstruction

\section{References}

Almog, Oz. 2000. The Sabra: The Creation of a New Jew. Berkeley: University of California Press.

Appadurai, Arjun. 1985. “Gratitude as a Social Mode in South India." Ethos 13(3):236-245.

Bourdieu, Pierre. 1977. Outline of a Theory of Practice. Cambridge: Cambridge University Press.

Cookson, Peter W. and Caroline H. Persell. 1991. “Race and Class in America's Elite Preparatory Boarding School: African Americans as 'Outsiders Within."' The Journal of Negro Education 60(2):219-228. of the self process, which first occurred during the graduates' boarding school days. Some examples of these additional practices are: the social gatherings that take place about a week before Remembrance Day; in these gatherings, the operation of a habitus considered to be "Oriental" (Oriental speech, eating Oriental dishes, listening to Oriental music); the joint trip to the boarding school on Remembrance Day; eating in an Oriental restaurant; the exposure to symbols associated with the new self; and recollecting old memories with former classmates. These acts, alongside the regular practice of participating in the Memorial Day ceremony, fulfill a critical role in the maintenance of the new self, years after it was first constructed at the boarding school. This research objective-understanding the ways in which subjects maintain the reconstruction of their self over many years-must continue to occupy the minds of all those who take interest in ethnographies and changes in the self, as well as those who are curious about the processes affiliated with the social construction of reality.

Durkheim, Emile. 1915. The Elementary Forms of the Religious Life. London: Allen and Unwin.

Feldman, Jackie. 2008. Above the Death Pits, Beneath the Flag: Youth Voyages to Poland and the Performance of Israeli National Identity. New York: Berghahn Books.

Gaztambide-Fernández, Rubén. 2009a. The Best of the Best: Becoming Elite at an American Boarding School. Cambridge, MA Harvard University Press.

Gaztambide-Fernández, Rubén. 2009b. “What Is an Elite Boarding School?" Review of Educational Research 79(3):1090-1128.
Goffman, Erving. 1961. Asylums. New York: Anchor Books.

Goodman, Yehudah and Nissim Mizrachi. 2008. "'The Holocaust Does Not Belong to European Jews Alone': The Differential Use of Memory Techniques in Israeli High Schools." American Ethnologist 35(1):95-114.

Handelman, Don. 1998. Models and Mirrors: Towards Anthropology of Public Events. New York: Berghahn Books.

Handelman, Don. 2004. Nationalism and the Israeli State. Oxford, New York: Berg.

Howard, Adam. 2008. Learning Privilege. New York: Routledge.

Howe, Alyssa. 2001. "Queer Pilgrimage: The San Francisco Homeland and Identity Tourism." Cultural Anthropology 16(1):35-61.

Karabel, Jerome. 2005. The Chosen: The Hidden History of Admission and Exclusion at Harvard, Yale, and Princeton. Boston: Houghton Mifflin.

Khan, Shamus. 2011. Privilege: The Making of an Adolescent Elite at St. Paul's School. Princeton: Princeton University Press.

Lomsky-Feder, Edna. 2004. “The Memorial Ceremony in Israeli Schools: Between the State and Civil Society." British Journal of Sociology of Education 25(3):291-305.

Sahlins, Marshall. 1995. How "Natives" Think About Captain Cook. Chicago: University of Chicago Press.

Shohat, Ella. 1999. "The Invention of the Mizrahim." Journal of Palestine Studies 29(1):5-20.
Shoshana, Avihu. 2012a. "Governmentality, New Population, and Subjectivity." Subjectivity 5:396-415.

Shoshana, Avihu. 2012b. "Classification, Subjectivities, and Personal Visibility." Sociological Forum 27(1):187-206

Smilansky, Moshe and David Nevo. 1970. The Gifted Disadvantaged: Report Number 2. Jerusalem: Henrietta Sold Institution (Hebrew).

Smilansky, Moshe and David Nevo. 1979. The Gifted Disadvantaged. A Ten Year Longitudinal Study of Compensatory Education in Israel. London: Gordon and Breach.

Strauss, Anselm and Juliet Corbin. 1998. Basics of Qualitative Re search. Thousand Oaks, CA: Sage.

Turner, Victor. 1969. The Ritual Process: Structure and Anti-Structure. London: Routledge.

Turner, Victor and Edith Turner. 1978. Image and Pilgrimage in Christine Culture: Anthropological Perspective. New York: Columbia University Press.

Urry, John. 1990. The Tourist Gaze: Leisure and Travel in Contemporary Societies. London: Sage.

Wallace, David Adams. 1995. Education for Extinction: American Indians and the Boarding School Experience 1875-1928. Lawrence, KS: University Press of Kansas.

Weinberg, Ian. 1967. The English Public Schools. New York: Atherton Press.

Zweigenhaft, Richard and William Domhoff. 1982. Jews in the Protestant Establishment. New York: Praeger. 